\title{
TINGKAT PENGETAHUAN ORANG TUA TENTANG COVID-19 DI RUANG RAWAT INAP PEDIATRIK RUMAH SAKIT ADVENT BANDUNG
}

\author{
Nani Simbolon ${ }^{1}$, Monalisa Sitompul ${ }^{2}$ \\ ${ }^{1,2}$ Fakultas Ilmu Keperawatan, Universitas Advent Indonesia \\ ${ }^{1}$ E-mail: nani.simbo@gmail.com
}

\begin{abstract}
Coronavirus Disease (COVID-19) is a pandemic disease caused by the Severe Acute Respiratory Syndrome Coronavirus-2 (SARS-CoV-2) and data from World Health Organization shows a massive increase in the number of confirmed cases from various countries. Purnamasari \& Raharyani (2020) said that the effort needed to break the chain of spreading COVID-19 is a good understanding and knowledge of COVID-19 from all elements of society, so that it can form behavior according to protocol and can break the chain of transmission of the COVID-19 virus. This study aims to describe the level of knowledge about COVID-19 in pediatric's parents at Bandung Adventist Hospital. This research design is descriptive quantitative, and the sample taken through total sampling with 50 people. The instrument used was a knowledge questionnaire about Covid-19. The result of this research found that the level of parents knowledge about COVID-19 is in the good category (84\%). As another effort to reduce the number of confirmed cases of COVID-19, researcher feel the need for further studies on the factors that affect the level of knowledge about COVID-19.
\end{abstract}

Keywords: Coronavirus Disease, Knowledge

\begin{abstract}
ABSTRAK
Coronavirus Disease 2019 (COVID-19) merupakan penyakit pandemi yang disebabkan oleh virus Severe Acute Respiratory Syndrome Coronavirus-2 (SARS-CoV-2), dan data organisasi kesehatan dunia menunjukkan adanya peningkatan jumlah kasus terkonfimasi dari berbagai negara secara masif. Purnamasari \& Raharyani (2020) mengatakan bahwa upaya yang dibutuhkan untuk memutuskan mata rantai penyebaran COVID-19 adalah pemahaman dan pengetahuan yang baik tentang COVID-19 dari seluruh elemen masyarakat, sehingga dapat membentuk perilaku yang sesuai dengan protokol dan dapat memutuskan mata rantai penularan virus COVID-19. Penelitian ini bertujuan untuk melihat gambaran tingkat pengetahuan orang tua pasien pediatrik yang dirawat di Rumah Sakit Advent Bandung. Desain penelitian ini adalah kuantitatif deskriptif, dan jumlah sampel yang diambil menggunakan teknik total sampling adalah sebanyak 50 orang. Instrumen yang digunakan adalah kuesioner pengetahuan tentang Covid-19. Hasil penelitian ini memperoleh gambaran tingkat pengetahuan orang tua tentang COVID-19 berada dalam kategori yang baik (84\%). Sebagai upaya lain untuk menekan angka kasus terkonfirmasi COVID-19, peneliti merasa perlunya dilakukan kajian lebih lanjut terhadap faktor-faktor yang mempengaruhi tingkat pengetahuan tentang COVID-19.
\end{abstract}

Kata Kunci: Coronavirus Disease, Pengetahuan 


\section{PENDAHULUAN}

Negara China Provinsi Hubei kota Wuhan mendapati beberapa warga mereka mengalami kasus pneumonia diawal Bulan Desember 2019 yang etiologinya belum diketahui pasti. Kasus pertama dikaitkan dengan pasar ikan di Wuhan dan sejak tanggal 18 Desember 2019 hingga 29 Desember 2019 hanya lima pasien yang dirawat dengan Acute Respiratory Distress Syndrome (ARDS). Kasus ARDS meningkat pesat dalam kurun waktu tiga hari, sejak 31 Desember 2019 hingga 3 Januari 2020 dilaporkan sebanyak 44 kasus, dan sampai kurang dari satu bulan penyakit ini telah menyebar ke berbagai provinsi lain di China, Thailand, Jepang, dan Korea Selatan (Susilo et al., 2020; Ren et al., 2020; Huang et al., 2021; WHO, 2020d).

World Health Organization (WHO, 2020a) mengatakan bahwa penyakit ini disebabkan oleh salah satu jenis coronavirus yang baru, dan untuk sementara waktu dinamakan sebagai 2019 novel coronavirus (2019-nCoV). Tanggal 11 Februari 2020 WHO mengumumkan nama baru virus ini adalah Coronavirus Disease (COVID-19) yang disebabkan oleh virus Severe Acute Respiratory Syndrome Coronavirus-2 (SARS-CoV-2).

SARS-CoV-2 ditularkan dari manusia ke manusia menyebabkan penyebaran luas dan cepat di negara China hingga ke 190 negara. WHO (2020b) mengumumkan sejak 12 Maret 2020 bahwa COVID-19 merupakan penyakit pandemik, dimana hingga tanggal 29 Maret 2020 terdapat 634.835 kasus terinfeksi dan 33.106 jumlah kematian di seluruh dunia. Angka terkonfirmasi positif terus bertambah, hingga tanggal 23 September 2020 dilaporkan kasus terkonfirmasi COVID-19 di dunia adalah sebanyak 31.375.325, termasuk didalamnya yang telah meninggal sebanyak 966.399 jiwa. Update WHO tanggal 23 September 2020 menunjukkan bahwa Asia menduduki peringkat ke dua terbanyak kasus terkonfirmasi COVID19 setelah negara Amerika, yaitu sebanyak 6.250.751 kasus. Indonesia menduduki peringkat ke-23 di dunia dan ke dua di Asia yaitu terdapat 252.923 kasus terkonfirmasi positif dan diantaranya 9.837 jiwa telah meninggal dunia. Update pusat Informasi dan Koordinasi COVID-19 Provinsi Jawa Barat serta Satuan Tugas Penanganan COVID-19 (2020) menampilkan data terbaru pada 23
September 2020, Provinsi Jawa Barat menduduki peringkat ke empat di Indonesia yaitu terdapat 18.593 kasus terkonfirmasi positif dan diantaranya 343 jiwa telah meninggal. Kota Bandung meduduki peringkat ke empat di Provinsi Jawa Barat dalam kasus terkonfimasi COVID-19 yaitu terdapat 1.390 kasus, yang diantaranya 50 jiwa telah meninggal dunia. Data yang ditampilkan oleh lembaga dunia dan nasional di atas dapat mengalami perubahan seiring dengan berjalannya waktu, dapat meningkat atau menurun.

Pengumpulan data WHO (2020c) dengan sistem yang canggih memungkinkan data kasus terkonfirmasi positif COVID-19 dari berbagai negara dapat terupdate setiap hari, dan data yang ditampilkan menunjukkan angka yang terus meningkat. Satuan Tugas Penanganan COVID-19 (2020) mengatakan bahwa kenaikan angka kasus terkonfirmasi COVID-19 disebabkan oleh ketidakpatuhan terhadap protokol kesehatan COVID-19, seperti menjaga jarak, mencuci tangan, dan menggunakan masker. Satuan Tugas penanganan COVID-19 bekerjasama dengan Badan Pusat Statistik Indonesia menunjukkan data yaitu 3 dari 10 orang tidak menjaga jarak dalam waktu satu minggu terakhir, 2 dari 10 masyarakat tidak mencuci tangan selama 20 detik, 4 dari 10 orang tidak menggunakan hand sanitizer, 2 dari 10 orang tidak menggunakan masker ketika berada di luar rumah, rata-rata 3-5\% dari populasi di Provinsi Jawa Barat tidak khawatir terhadap virus COVID-19, dan 15-30\% masyarakat merasa tidak beresiko tertular (Satuan Tugas Penanganan COVID-19, 2020).

Purnamasari \& Raharyani (2020) mengatakan bahwa upaya yang dibutuhkan untuk memutuskan mata rantai penyebaran COVID19 adalah pemahaman dan pengetahuan yang baik tentang COVID-19 dari seluruh elemen masyarakat. Pengetahuan merupakan domain terpenting dalam terbentuknya perilaku, sebagai suatu hasil dari rasa ingin tahu melalui proses sensoris, terutama pada mata dan telinga terhadap objek tertentu (Donsu, 2017). Pengetahuan memegang peranan penting dalam menentukan perilaku yang utuh melalui pembentukan kepercayaan seseorang dan selanjutnya memberikan dasar bagi pengambilan keputusan, dan menentukan 
perilaku terhadap objek tertentu (Novita et al., 2014).

Penelitian Sari \& 'Atiqoh (2020) yang menunjukkan bahwa pengetahuan memiliki hubungan dengan kepatuhan. Oleh sebab itu, pengetahuan tentang penyakit Covid-19 merupakan hal yang sangat penting agar tidak menimbulkan peningkatan jumlah kasus terkonfirmasi positif COVID. Mempunyai pengetahuan yang baik tentang penyakit COVID-19 merupakan hal sangat penting untuk mencegah penyebaran dan peningkatan angka kasus terkonfirmasi (Sembiring \& Meo, 2020). Mona (2020) mengatakan bahwa sangat penting untuk mengetahui bagaimana cara penularan COVID-19, cara pencegahan, pengobatan, dan komplikasi.

Pendidikan kesehatan tentang COVID-19 telah disebarkan oleh pemerintah melalui berbagai media, akan tetapi masih banyak masyarakat yang belum memahaminya (Bekti et al. (2020). Hasil temuan peneliti selama masa pandemi ketika bekerja di layanan kesehatan ruang pediatrik, pasien dan keluarga sering meminta ijin kepada tenaga kesehatan agar diberi ijin dibesuk oleh beberapa kerabat jauh. Peneliti juga menemukan 3 dari 6 orang penunggu pasien tidak menggunakan masker ketika berada di ruangan pasien, dan 2 dari 3 orang yang memakai masker tidak menggunakan masker dengan baik dan benar. Berdasarkan uraian di atas, peneliti merasa perlu untuk mengetahui gambaran tingkat pengetahuan orang tua tentang COVID-19 di ruang rawat inap pediatrik Rumah Sakit Advent Bandung.

\section{METODE}

Penelitian ini merupakan penelitian kuantitatif deskriptif. Populasi dalam penelitian ini adalah orang tua pasien di ruang pediatrik Rumah sakit Advent Bandung. Responden penelitian diambil menggunakan total sampling. Dalam periode waktu pengumpulan data yang dimulai pada bulan Desember 2020 hingga Januari 2021, peneliti memperoleh 50 sampel dalam penelitian ini.

Instrumen yang digunakan adalah lembar kuesioner tingkat pengetahuan tentang Covid-
19. Kuesioner ini terdiri atas 18 pernyataan favorable dengan pilihan jawaban benar dan salah, serta terdiri atas pengertian dan penyebab (item 1 dan 2), transmisi penyebaran (item $3,4,5,6,7$ ), tanda dan gejala (item 8,9,10), pencegahan (item 12,13,14,15,18), komplikasi/akibat fatal (item 16), dan tindak lanjut (item 11 dan 17). Kuesioner ini disusun sendiri oleh peneliti dan telah lulus uji validitas dan reliabilitas, yaitu nilai validitas $>0,893$ dan cronbach's alpha 0,937 .

Pengumpulan data dilakukan di Ruang Rawat Inap Pediatrik Rumah Sakit Advent Bandung, Jl. Cihampelas No.161, Cipaganti, Kecamatan Coblong, Kota Bandung, Jawa Barat pada bulan Desember 2020 hingga Januari 2021. Penelitian ini sudah lulus uji etik dari Komite Etik Penelitian Kesehatan Fakultas Ilmu Keperawatan Universitas Advent Indonesia dengan nomor 124/KEPK-FIK.UNAI/EC/XI/20 dan sudah mendapat surat izin dari pihak Rumah Sakit Advent Bandung dengan nomor surat 770/EXCOM.RSAB/XII/2020.

Pengumpulan data dilakukan dengan cara menemui langsung orang tua pasien yang sedang dirawat di ruang pediatrik. Peneliti menjelaskan tujuan dan maksud penelitian kepada sampel, dan meminta pasien untuk menandatangani informed consent secara sukarela. Sample yang telah menandatangani informed consent akan diberikan kuesioner penelitian. Peneliti memastikan bahwa seluruh item kuesioner telah diisi.

Kuesioner yang telah dikumpulkan akan ditabulasi dengan menggukan microsoft excel. Analisis data dilakukan dengan menggunakan nilai rata-rata persentasi skor responden, dengan metode skoring, jawaban yang benar diberi nilai 1 (satu) dan jawaban yang salah nilai nol (0). Nilai persentasi yang diperoleh akan dikategorikan berdasarkan skor tingkat pengetahuan, yaitu $90-100 \%$ adalah pengetahuan yang sangat baik, $80-89 \%$ adalah pengetahuan baik, $70-79 \%$ adalah pengetahuan cukup, $<70 \%$ adalah pengetahuan kurang (Saputra \& Simbolon, 2020). 


\section{HASIL}

Sebanyak 50 responden telah mengisi kuesioner dengan lengkap. Berikut ini adalah informasi hasil tabulasi data kuesioner dalam penelitian ini.

Tabel 1. Karakteristik Data Responden

\begin{tabular}{cllcc}
\hline No & & Karakteristik & N & \% \\
\hline 1 & Jenis Kelamin & Laki-laki & 14 & 28 \\
& & Perempuan & 36 & 72 \\
2 & Usia & 17-25 Tahun & 7 & 14 \\
& & 26-35 Tahun & 21 & 42 \\
3 & \multirow{4}{*}{ Pendidikan Terakhir } & 36- 45 Tahun & 22 & 44 \\
& & SMP & 2 & 4 \\
& & SMA & 28 & 56 \\
& & Diploma II & 1 & 2 \\
& & Diploma III & 5 & 10 \\
& & Diploma IV & 2 & 4 \\
4 & \multirow{4}{*}{ Pekerjaan } & Stratum 1 & 11 & 22 \\
& & Stratum 2 & 1 & 2 \\
& & Ibu rumah tangga & 18 & 36 \\
& & Guru & 1 & 2 \\
& & Pendeta & 1 & 2 \\
& & Karyawan BUMN & 1 & 2 \\
& & Karyawan swasta & 25 & 50 \\
& & Wirausaha & 4 & 8 \\
\hline
\end{tabular}

Tabel 2. Pengetahuan Orang Tua tentang COVID-19

\begin{tabular}{|c|c|c|c|}
\hline No & Pertanyaan & $\mathbf{N}$ & $\%$ \\
\hline 1 & COVID-19 adalah penyakit menular & 49 & 98 \\
\hline 2 & COVID-19 disebabkan oleh virus corona baru yaitu SARS-CoV-2 & 48 & 96 \\
\hline 3 & Orang yang positif COVID dapat menularkan virus saat batuk & 49 & 98 \\
\hline 4 & Orang yang positif COVID tidak dapat menularkan virus saat bersin & 9 & 18 \\
\hline 5 & $\begin{array}{l}\text { Orang yang positif COVID tidak dapat menularkan virus saat } \\
\text { menghembusankan nafas }\end{array}$ & 35 & 70 \\
\hline 6 & $\begin{array}{l}\text { Virus corona tidak dapat masuk ketubuh manusia melalui mata dan rongga } \\
\text { mulut }\end{array}$ & 40 & 80 \\
\hline 7 & Pintu masuk Virus corona ke tubuh manusia adalah melalui rongga hidung & 31 & 62 \\
\hline 8 & $\begin{array}{l}\text { Orang yang positif COVID, kadang-kadang tidak menunjukkan gejala atau } \\
\text { terlihat seperti orang sehat }\end{array}$ & 45 & 90 \\
\hline 9 & $\begin{array}{l}\text { Demam, batuk, lemah, dan sakit tenggorokan adalah tanda dan gejala } \\
\text { COVID }\end{array}$ & 49 & 98 \\
\hline 10 & $\begin{array}{l}\text { Tanda dan gejala COVID } 19 \text { adalah sesak nafas, demam tinggi, nyeri perut, } \\
\text { dan batuk }\end{array}$ & 50 & 100 \\
\hline 11 & $\begin{array}{l}\text { Untuk menetapkan pasien COVID-19, Orang dengan riwayat demam tinggi, } \\
\text { sesak nafas, sakit tenggorokan, dan batuk harus menjalani pemeriksaan dan } \\
\text { screening COVID-19 }\end{array}$ & 47 & 94 \\
\hline 12 & $\begin{array}{l}\text { Sering mencuci tangan dengan air mengalir dan sabun atau menggunakan } \\
\text { hand sanitizer dapat membunuh virus corona }\end{array}$ & 49 & 98 \\
\hline 13 & Menggunakan masker dapat mencegah penularan virus corona & 49 & 98 \\
\hline 14 & Menjaga jarak harus dilakukan untuk mencegah penularan virus corona & 48 & 96 \\
\hline 15 & $\begin{array}{l}\text { Menyentuh area wajah sebelum mencuci tangan tidak beresiko terinfeksi } \\
\text { virus corona }\end{array}$ & 40 & 80 \\
\hline 16 & Virus corona tidak dapat menyebabkan kematian & 41 & 82 \\
\hline 17 & Orang yang positif COVID tidak harus di isolasi & 39 & 78 \\
\hline 18 & $\begin{array}{l}\text { Membersihkan secara rutin permukaan dan benda yang sering disentuh } \\
\text { adalah salah satu langkah untuk pencegahan penularan COVID }\end{array}$ & 47 & 94 \\
\hline & Rata-rata & 43 & 85 \\
\hline
\end{tabular}


Tabel 3. Tingkat Pengetahuan Orang Tua

\begin{tabular}{cccc}
\hline No & Tingkat Pengetahuan & N & \% \\
\hline 1 & Sangat baik & 20 & 40 \\
2 & Baik & 18 & 36 \\
3 & Cukup & 5 & 10 \\
4 & Kurang & 7 & 14 \\
& Total & 50 & 100 \\
\hline
\end{tabular}

Informasi data pada tabel 1 menunjukkan responden yang berjenis kelamin perempuan berjumlah 36 orang $(72 \%)$ sedangkan sisanya adalah laki-laki (14 orang/28\%). Usia 17-25 Tahun berjumlah 7 orang (14\%), usia 26-35 Tahun berjumlah 21 orang (42\%), dan usia 3645 Tahun sebanyak 22 orang (44\%). Karateristik reponden berdasarkan pendidikan terakhir, SMP berjumlah 2 orang (4\%), SMA 28 orang $(56 \%)$, Diploma II hanya 1 orang (2\%), Diploma III berjumlah 5 orang (10\%), Stratum 1 dan Stratum 2 masing-masing hanya berjumlah 1 orang (2\%). Responden yang berprofesi sebagai ibu rumah tangga sebanyak 18 orang (36\%); Guru, Pendeta, dan karyawan BUMN masing-masing berjumlah 1 orang (2\%); karyawan swasta ada 25 orang (20\%); dan wirausaha hanya 4 orang $(8 \%)$.

Informasi tabulasi data pada tabel 2 menunjukkan pengetahuan orang tua berdasarkan item pernyataan. Ditemukan 49 orang (98\%) tahu bahwa COVID-19 adalah penyakit menular, dapat menular saat orang terkonfimasi positif sedang batuk, tahu tanda dan gejala COVID-19, tahu pencegahan melalui cuci tangan dan menggunakan masker. 48 orang $(96 \%)$ tahu nama virus penyebab COVID-19, serta tahu bahwa menjaga jarak harus dilakukan untuk mencegah penularan COVID-19. Sebanyak 47 orang (94\%) tahu bahwa tindakan membersihkan permukaan dan benda yang sering disentuh dapat mencegah penularan COVID-19, serta tahu tindakan lanjut jika mengalami gejala gangguan pernafasan. Mayoritas dari 45 orang (90\%) tahu bahwa orang yang positif COVID-19 kadang-kadang tidak menunjukkan gejala atau terlihat seperti orang sehat. 41 orang $(82 \%)$ tahu bahwa virus corona dapat menyebabkan kematian. 39 orang (78\%) tahu bahwa orang yang positif COVID harus di isolasi. 35 orang (70\%) tahu bahwa orang yang positif COVID dapat menularkan virus saat menghembuskan nafas. 31 orang (62\%) tahu pintu masuk virus corona ke tubuh manusia adalah melalui rongga hidung. Dan hanya 9 orang (18) tahu bahwa orang yang positif COVID dapat menularkan virus saat bersin.

Tabulasi data pada tabel 3 menunjukkan tingkat pengetahuan orang tua pasien anak yang dirawat di ruang pediatrik tentang COVID-19. Ditemukan bahwa 20 orang (40\%) memiliki pengetahuan yang sangat baik, 18 orang (36\%) berpengetahuan baik, 5 orang $(10 \%)$ memiliki pengetahuan yang cukup, dan sebanyak 7 orang (14\%) memiliki pengetahuan yang kurang. Pada tabel 2 dapat diketahui nilai rata-rata persentase pengetahuan orang tua adalah $85 \%$. Berdasarkan skor tingkat pengetahaun, maka tingkat pengetahuan orang tua pasien anak yang dirawat di ruang pediatrik Rumah Sakit Advent Bandung berada pada kategori yang baik.

\section{PEMBAHASAN}

Hasil tabulasi data dalam penelitian ini memberikan informasi bahwa mayoritas orang tua yang mendampingi pasien anak yang dirawat di ruang pediatrik Rumah Sakit Advent adalah perempuan, dan mayoritas berusia 3645 tahun yang berada pada masa dewasa akhir. Mayoritas responden memiliki pendidikan terakhir Sekolah Menengah Atas (SMA), dan memiliki pekerjaan sebagai karyawan swasta. Menurut Amin \& Juniati (2017) usia 36-45 Tahun merupakan masa dewasa akhir dan produktif, serta memilik anak dalam rentang usia 11 -20 Tahun atau tergantung pasa usia ibu ketika sedang mengandung.

Gambaran pengetahuan pada mayoritas orang tua berada pada kategori yang baik, namun ditemukan pengetahuan yang cukup dan kurang dalam jumlah kecil diantara responden. Hasil penelitian ini didukung oleh penelitian 
Yanti et al. (2020) yang mengatakan bahwa pada saat ini pengetahuan masyarakat tentang COVID-19 berada pada kategori yang baik dan telah mematuhi protokol kesehatan di masa pandemi, dengan kategori kasus di masyarakat berada pada kategori yang ringan. Sanifah (2018) dan Yuliana (2017) menambahkan bahwa pengetahuan seseorang dapat dipengaruhi berbagai faktor, diantaranya adalah faktor usia, pendidikan, pekerjaan, pengalaman, informasi, sosial budaya dan ekonomi, dan lingkungan.

Orang tua menginginkan agar anak mereka selalu sehat dan aman khususnya pada masa pandemi COVID-19. Peran orang tua sangat diharapkan dalam upaya pemutusan rantai penyebaran virus corona. Oleh karena itu, melalui pengetahuan yang baik, orang tua dapat melindugi anggota keluarga dari berbagai serangan yang menyebabkan gangguan fungsi dan gangguan kesehatan yang disebabkan COVID-19 (Karuniawati \& Putrianti, 2020).

Pengetahuan adalah suatu keadaan "tahu" setelah melakukan pengindraan terhadap suatu objek, termasuk melalui indra penglihatan dan pendengaran (Priantara, 2019). Pengetahuan akan memberikan bimbingan terhadap baik dan buruk suatu ide dan keadaan, serta akan menghasilkan perubahan sikap dan tingkah laku individu (Kuri, 2016).

Tabulasi data primer penelitian ini menunjukkan bahwa mayoritas orang tua memiliki pengetahuan di atas kategori baik terhadap semua item pernyataan, termasuk pengertian dan nama virus COVID-19, tanda dan gejala serta pencegahan COVID-19, dan akibat fatal serta tindak lanjut COVID-19. Meskipun demikian didapati pengetahuan di bawah kategori cukup yaitu pada bagian transmisi penyebaran COVID dan tindak lanjut untuk orang yang terkonfirmasi.

Menurut Burhan et al. (2020) semua orang yang terkonfirmasi COVID-19 harus dipisahkan dari lingkungan atau orang yang sehat dengan tujuan untuk memutus rantai penyebaran COVID-19. WHO (2020d) mengatakan bahwa terdapat kemungkinankemungkian model transmisi SARS-CoV-2, diantaranya adalah transmisi kontak, droplet, udara (air bone), fomit, dan dari binatang ke manusia. Transmisi kontak dapat terjadi secara langsung dan tidak langsung melalui sekresi air liur dan sekresi saluran nafas saat orang terkonfimasi positif sedang batuk, bersin, berbicara, menguap, dan lain sebagainya. Transmisi melalui udara diakibatkan droplet yang mengandung SARS-CoV-2 melayang di udara dan dapat bertahan hidup dalam kurun waktu 3-16 jam di udara. Transmisi fomit terjadi terjadi saat droplet terinfeksi mengkontaminasi permukaan dan virus dapat hidup selama berjam-jam tergantung suhu dan kelembapan serta jenis permukaan, sehingga seseorang yang menyentuh area fomit dan dilanjutkan menyentuh area wajah, mulut, hidung, dan mata dapat terinfeksi virus corona.

Dalam menghadapi pandemi COVID-19 sangat diperlukan kerjasama yang baik dari seluruh lapisan masyarakat. Kesadaran akan bahaya COVID-19 harus selalu dicanangkan dan setiap oknum harus tetap menjalankan protokol kesehatan pada era pandemi COVID19. Tugas tenaga kesehatan khususnya perawat sangat dibutuhkan dalam hal promotif dan preventif tanpa mengabaikan kuratif dan rehabilitatif secara menyeluruh dan terpadu. Pelayanan kesehatan bukan saja tertuju kepada orang sakit tetapi seluruh individu yang terhubung dengan orang sakit dan juga orang sehat, sehingga pada akhirnya masyarakat berada pada derajat kesehatan yang baik (Weta, 2020).

\section{KESIMPULAN DAN SARAN}

Berdasarkan hasil penelitian ini, peneliti menyimpulkan bahwa orang tua pasien yang sedang menjaga anaknya di ruang rawat inap pediatrik Rumah Sakit Advent Bandung, memiliki tingkat pengetahuan yang baik tentang COVID 19. Hal ini dapat dipengaruhi oleh usia, pendidikan, pengalaman mematuhi protokol ketika bekerja, serta informasi yang diperoleh melalu media massa yang ada. Seperti pendapat dari berbagai peneliti menunjukkan bahwa usia, pendidikan, pekerjaan, pengalaman, dan media komunikasi merupakan faktor yang dapat mempengaruhi pengetahuan seseorang (Syaipudin, 2019; Sanifah, 2018; Yuliana, 2017).

Saran dari peneliti adalah agar perawat sebagai tenaga profesional kesehatan harus mampu menjalankan fungsinya untuk mempertahankan 
dan meningkat pengetahuan seseorang sehingga tercipta perilaku yang diharapkan. Peran perawat bukan hanya sebagai pemberi perawatan, tetapi dituntut agar mampu sebagai seorang pendidik, hal ini ditujukan agar seseorang menjadi tahu yang benar, sehingga timbul perilaku yang benar.

Rumah Sakit sebagai salah satu fasilitas kesehatan diharapkan mampu mempertahankan dan meningkatkan usahanya dalam upaya penerapan protokol kesehatan melalui screening pasien dan pengunjung yang datang ke layanan kesehatan, juga dalam penyebaran informasi dan edukasi melalui spanduk dan banner, serta ketersediaan fasilitas seperti hand rub, washtafel, dan sabun cuci tangan.

Bagi peneliti selanjutnya perlu untuk mengkaji tentang hubungan faktor-faktor yang mempengaruhi tingkat pengetahuan tentang COVID-19. Kajian ini perlu dilakukan, sebagai upaya untuk menekan angka kasus terkonfirmasi COVID-19.

\section{DAFTAR PUSTAKA}

Amin, M. A. A., \& Juniati, D. (2017). Klasifikasi kelompok umur manusia berdasarkan analisis dimensi fraktal box counting dari citra wajah dengan deteksi tepi canny. Jurnal Ilmiah Matematika, 2(6), 33-42. Retrieved Februari 1, 2021, from

https://media.neliti.com/media/publicatio ns/249455-none-23b6a822.pdf

Bekti, R. D., Suryowati, K., \& Prasetyo, H. (2020). Pengaruh kehidupan sosial ekonomi penduduk terhadap pengetahuan dan perilaku pencegahan Covid-19. Badan Riset dan Inovasi Nasional Republik Indonesia. Retrieved November 1, 2020, from http://sinta.ristekbrin.go.id/covid/peneliti an/detail/182

Burhan, E., Susanto, A. D., Nasution, S. A., \& Ginanjar, E. (2020). Pedoman Tatalaksana COVID-19 (Edisi 2). Jakarta: Perhimpunan Dokter Paru Indonesia (PDPI), Perhimpunan Dokter Spesialis Kardiovaskular Indonesia (PERKI), Perhimpunan Dokter Spesialis Penyakit Dalam Indonesia (PAPDI), Perhimpunan Dokter Anestesiologi dan
Terapi Intensif Indonesia (PERDATIN), Ikatan Dokter. Retrieved Februari 1, 2021 , from https://www.papdi.or.id/pdfs/938/Pedoma n Tatalaksana COVID-19 edisi 2.pdf

Donsu, J. D. . (2017). Psikologi Keperawatan (Cetakan I). Pustaka Baru Press.

Huang, C., Wang, Y., Ren, L., Zhao, J., \& Hu, Y. (2021). Clinical features of patiens infected with 2019 Novel Coronavirus in Wuhan, China. Elsevire, 395, 497-506. doi: $\quad$ https://doi.org/10.1016/S01406736(20)30183-5

Karuniawati, B., \& Putrianti, B. (2020). Gambaran perilaku hidup bersih dan sehat (PHBS) dalam pencegahan penularan COVID-19. Jurnal Kesehatan Karya Husada (JKKH), 8(2), 34-53. doi: https://doi.org/10.36577/jkkh.v8i2.411

Kuri. (2016). Manfaat ilmu pengetahuan dalam persepektif Hindu. Jurnal Widya Katambung, 7(1), 2089-6662. Retrieved Maret 12, 2021, from https://core.ac.uk/download/pdf/2859854 88.pdf

Mona, N. (2020). Konsep isolasi dalam jaringan sosial untuk meminimalisasi efek contagious (kasus penyebaran virus corona di Indonesia). Jurnal Sosial Humaniora Terapan, 2(2), 117-125. doi: https://doi.org/10.7454/jsht.v2i2.86

Novita, N. W., Yuliastuti, C., \& Narsih. (2014). Tingkat pengetahuan tentang TB paru mempengaruhi penggunaan masker di ruang paru Rumkital Dr. Ramelan Surabaya. Jurnal Ilmiah Kesehatan, 7(7). doi: https://doi.org/10.33086/jhs.v7i1.486

Priantara, T. (2019). Tingkat Pengetahuan Siswa Kelas V terhadap Kesehatan Lingkungan Sekolah di SD Negeri Gugus Minomartani Kecamatan Ngaglik Kabupaten Sleman. Skripsi. Yogyakarta: Universitas Negeri Yogyakarta.

Purnamasari, I., \& Raharyani, A. E. (2020). Tingkat pengetahuan dan perilaku masyarakat Kabupaten Wonosobo tentang Covid-19. Jurnal Ilmiah Kesehatan, 33-42.

Ren, L. L., Wang, Y. M., Wu, Z. Q., Xiang, Z. 
C., \& Guo, L. (2020). Identification of novel coronavirus causing severe pneumonia in human: A desciptive study. Chinese Medical Journal, 133(9), 10151024. doi:

10.1097/CM9.0000000000000722

Sanifah, L. J. (2018). Hubungan tingkat pengetahuan dengan sikap keluarga tentang perawatan activities daily living (ADL) pada lansia. Skripsi. Jombang: Sekolah Tinggi Ilmu Kesehatan Insan Cendekia Media.

Saputra, A. W., \& Simbolon, I. (2020). Hubungan tingkat pengetahaun tentang covid-19 terhadap kepatuhan program lockdown untuk mengurangi penyebab Covid-19 di kalangan mahasiswa berasrama Universitas Advent Indonesia. Nutrix Journal, 4(2), 1-7. doi: https://doi.org/10.37771/nj.Vol4.Iss2.470

Sari, D. P., \& 'Atiqoh, N. S. (2020). Hubungan antara pengetahuan masyarakat dengan kepatuhan penggunaan masker sebagai upaya pencegahan penyakit COVID-19 di Ngronggah. Jurnal Ilmiah Rekam Medis dan Informatika Kesehatan, 10(1), 52-55. doi: https://doi.org/10.47701/infokes.v10i1.85 0

Satuan Tugas Penanganan COVID-19. (2020). Situasi COVID-19 di Indonesia. Retrieved Maret 12, 2021, from https://covid19.go.id/

Sembiring, E. E., \& Meo, M. L. N. (2020). Pengetahuan dan sikap berhubungan dengan resiko tertular Covid-19 pada masyarakat Sulawesi Utara. Jurnal Keperawatan, 16(2), 75-82. doi: https://doi.org/10.25077/njk.16.2.7582.2020

Susilo, A., Rumende, C. M., Pitoyo, C., Santoso, W. D., Yulianti, M., \& Herikurniawan. (2020). Coronavirus disease 2019: Tinjauan literatur terkini. Jurnal Penyakit Dalam Indoneisia, 7(1), 46-67. doi: http://dx.doi.org/10.7454/jpdi.v7i1.415

Syaipudin, L. (2019). Efektifitas media komunikasi di tengah pandemi: Respon gugus tugas percepatan penanganan Covid-19 Kabupaten Tulungagung. Kalijaga Journal of Communication, 1(2),
165-178. doi: https://doi.org/10.14421/kjc.12.06.2019

Weta, K. A. (2020). Gambaran persepsi masyarakat tentang peran perawat Puskesmas pada masa COVID-19 di Kota Kupang . Skripsi. Kupang: Universitas Citra Bangsa Retrieved Februari 1, 2021, from http://repository.ucb.ac.id/524/1/SKRIPS I-KRISTINA A.WETA-131111072.pdf

WHO. (2020a). Naming the Coronavirus Disease (COVID-19) and the Virus that Causes It. Retrieved November 1, 2020, from https://www.who.int/

WHO. (2020b). Situation by Country, Territory \& Area. Retrieved November 1 , 2020, from https://www.who.int/

WHO. (2020c). Timeline: WHO's COVID-19 response. Retrieved November 1, 2020, from https://www.who.int/

WHO. (2020d). Transmisi SARS-CoV-2: Implikasi terhadap Kewaspadaan Pencegahan Infeksi. Retrieved November 1, 2020, from https://www.who.int/docs/defaultsource/searo/indonesia/covid19/transmisi -sars-cov-2---implikasi-untuk-terhadapkewaspadaan-pencegahan-infeksi--pernyataankeilmuan.pdf?sfvrsn=1534d7df_4

WHO. (2020e). WHO Coronavirus Disease (COVID-19) Dashboard. Retrieved November 1, 2020, from https://www.who.int/

Yanti, N. P. D., Nugraha, I. M. A. D., Wisnara, G. A., \& Dian, N. P. (2020). Gambaran pengetahuan masyarakat tentang COVID19 dan perilaku masyarakat di masa pandemi COVID-19. Jurnal Keperawatan Jiwa, 3, 491-504. Retrieved Februari 1, 2021, from https://jurnal.unimus.ac.id/index.php/JKJ/ article/download/6173/pdf

Yuliana, E. (2017). Analisis pengetahuan siswa tentang makanan yang sehat dan bergizi terhadap pemilihan jajanan di Sekolah. Skripsi. Purwekerto: Universitas Muhammadiyah Purwokerto. Retrieved November 1, 2020, from http://repository.ump.ac.id/4114/ 